\title{
Self-Similar Magnetoconductance Fluctuations Induced by Self- Similar Periodic Orbits
}

\section{$\operatorname{AUTHOR}(\mathrm{S})$ :}

Budiyono, Agung; Nakamura, Katsuhiro

\section{CITATION:}

Budiyono, Agung ...[et al]. Self-Similar Magnetoconductance Fluctuations Induced by SelfSimilar Periodic Orbits. 物性研究 2002, 78(3): 293-294

ISSUE DATE:

2002-06-20

URL:

http://hdl.handle.net/2433/97228

RIGHT: 


\section{自己相似周期軌道に誘起された自己相似磁気伝導 \\ Self-Similar Magnetoconductance Fluctuations \\ Induced by Self-Similar Periodic Orbits ${ }^{1}$}

$$
\text { アグンブディヨノ，中村 勝弘 }
$$

Agung Budiyono, Nakamura Katsuhiro

大阪市立大学大学院工学研究科

Department of Applied Physics, Osaka City University

量子ドットで最近観測されているフラクタルな磁気伝導を半古典久保公式を使って、周期軌道 の描像を与え説明します。実験で得られたフラクタル磁気伝導はサドルに向かっている真っ直ぐな 周期軌道から pitchfork-isochronous 分岐を通して生まれてくる自己相似な周期軌道のファミリー によって、説明できます。サドルは実験で避けられないソフトなポテンシャル閉じ込めによって、 自然に、量子ドットとリードとの点接合部に出来ています。我々の計算によると、フラクタル摇 らぎの次元は量子ドットの細かい形にはよらず、リードで出来るサドルの曲率で決まっています。

Using the semiclassical Kubo formula for conductivity, we give a periodic-orbits picture for the recently observed fractal magnetoconductance fluctuations in micron-sized phase coherent ballistic billiards. The self-similar conductance fluctuations is shown to be caused by the self-similar unstable periodic orbits which are generated through a sequence of isochronous pitchfork bifurcations of straight-line librating orbits oscillating towards harmonic saddles. The saddles are naturally created right at the point of contact with the leads or at certain places in the cavity as a consequence of the softwall confinement. Therefore our mechanism is able to explain all the self-similar magnetoconductance fluctuations in general softwall billiards. In contrast to the existing theory which claims that a classical mixed phase space is necessary, we argue that, even in the fully chaotic phase space, the self-similar magnetoconductance fluctuations should be observed as long as the self-similar unstable periodic orbits are preserved.

Without loss of generality, to make our idea clearly presented, we choose Henon-Heiles potensial as the ideal soft wall model for triangle billiard with three leads attached at its three edges. The harmonic saddles are obvious. The self-similar periodic orbits are then, created through bifurcation of the straight librating orbits oscillates towards/backward the leads. From the self similarity of the orbits, we have the following approximate scaling relation:

$$
\Theta_{p o}^{n}=\lambda \Theta_{p o}^{n-1}, \quad 0<\lambda<1 .
$$

Here $\Theta_{p o}^{n}$ denotes the area enclosed by the periodic orbit generated at the $n^{\text {th }}$ bifurcation.

The oscillating part of the conductance can be approximated by the semiclassical Kubo formula in terms of periodic orbits as follows

$$
\begin{aligned}
\delta G_{x x}(E, B)=\frac{g e^{2}}{h V} \sum_{p o} C_{x x}^{p o} & \frac{R_{p o}\left(\tau_{\beta}\right) F_{p o}\left(\tau_{s}\right)}{\left\|\operatorname{Det}\left(\tilde{M}_{p o}-I\right)\right\|^{1 / 2}} \\
& \times \cos \left(\frac{S_{p o}}{\hbar}+\frac{\mu_{p o}}{2} \pi\right) .
\end{aligned}
$$

${ }^{1}$ to be submitted 


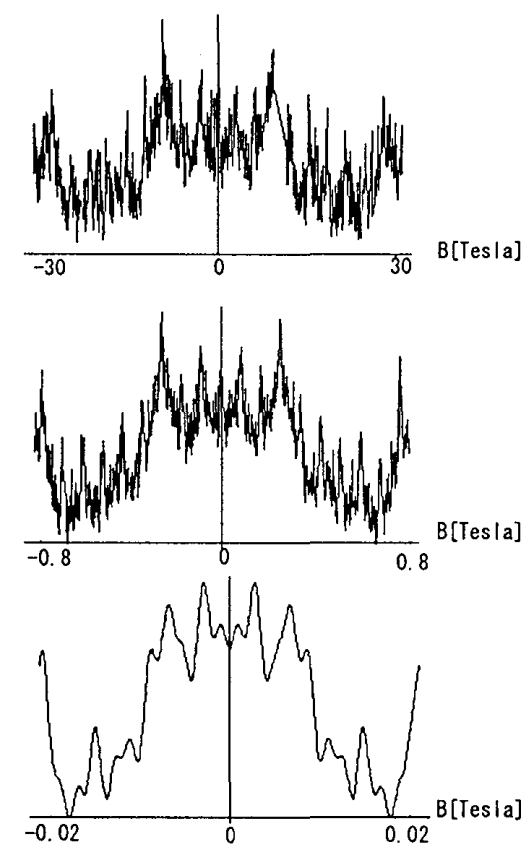

Figure 1: Succesive magnifications of fractal fluctuations of $\delta G_{x x}$ around $B=0$ Tesla, for $T=0.01$ Kelvin. The vertical coordinate is scaled in arbitrary unit. The scale factor of each magnification in the horizontal direction is equal to 40.

Here $S_{p o}$ is the action evaluated at the Fermi energy $E_{F} . \mu_{p o}$ and $\tilde{M}_{p o}$ are the Maslov index and the stability matrix of each periodic orbit, respectively. The temperature $T$ selects only a few shortest periodic orbits that contribute to the trace through a damping factor $R_{p o}\left(\tau_{\beta}\right)=\left(T_{p o} / \tau_{\beta}\right) / \sinh \left(T_{p o} / \tau_{\beta}\right)$, where $T_{p o}$ is the period of the periodic orbits and $\tau_{\beta}=\frac{\hbar}{\pi k T}$. Damping due to a finite mean free path is given by $F_{p o}\left(\tau_{s}\right)=\exp \left(-T_{p o} / 2 \tau_{s}\right)$, where $\tau_{s}$ is the scattering time. $g$ is a spin factor, $V$ is the volume of the system considered, and $C_{x x}$ is the velocity-velocity correlation function of the periodic orbit, defined by

$$
C_{x x}^{p o}=\int_{0}^{\infty} d t e^{-t / \tau_{s}} \int_{0}^{T_{p o}} d t^{\prime} v_{x}\left(t^{\prime}\right) v_{x}\left(t^{\prime}+t\right)
$$

On switching on a small magnetic field $B$, we can assume that only the phase of the electron is changed, and the periodic orbits (the phase-space structure) remain unchanged. Then we can expand $S_{p o}$ up to the first order in $B$ as follows:

$$
S_{p o}(E, B)=S_{p o}(E, 0)+\frac{e}{c} \Theta_{p o} B
$$

Where $\Theta_{p o}$ is the area enclosed by each periodic orbit. For weak enough magnetic field $B$, considering the contributions from $\pm \Theta_{p o}$, i.e., from a pair of time-reversal symmetric orbits, we can rewrite the cosine terms as $2 \cos \left(\frac{S_{p o}(E, 0)}{\hbar}+\frac{\mu_{p o}}{2} \pi\right) \cos \left(\frac{e}{\hbar c} \Theta_{p o} B\right)$. Now, let us suppose that, through some kind of bifurcations, we have a sequence of periodic orbits which are self similar, and satisfy Eq. (1). Then we can expect that the fluctuations of the magnetoconductance should be characterized by many scales, with the smallest one being $\Theta_{p o}^{0}$, i.e., the largest area enclosed by the periodic orbits. 